\title{
MENINGKATKAN MUTU PENDIDIKAN ATAU MENJAMIN MUTU PENDIDIKAN MELALUI SUPERVISI PENDIDIKAN UNTUK MENCAPAI KUALITAS PENDIDIKAN NASIONAL
}

"Peranan Supervisi Pendidikan Untuk Meningkatkan Mutu Pendidikan Pendidikan Nasional"

\author{
Di Susun Oleh : \\ Viranti \\ E-mail :rantinti02@gmail.com
}

\begin{abstract}
"Education is very important in the survival of the nation. Talking about the implementation of education is inseparable from problems. One of the solutions that can be taken as a necessity is supervision which encourages the spirit of teachers and education staff to do better and more effectively"
\end{abstract}

Keywords : education

\section{PENDAHULUAN}

\section{Latar Belakang}

Mutu pendidikan merupakan isu yang terus menerus akan menjadi perbincangan dalam pengelolan/ manajemen pendidikan. Peningkatan mutu pendidikan merupakan usaha yang harus diupayakan dengan terus menerus agar harapan untuk pendidikan yang berkualitas dan relevan dapat tercapai.

Guru memiliki potensi untuk berkreasi dan meningkatkan kinerjanya. Namun demikian seringkali banyak faktor yang menghambat mereka dalam mengembangkan berbagai potensinya secara optimal, baik itu berupa kemampuan guru itu sendiri dalam proses belajar mengajar, maupun sarana dan prasarana pendidikan yang tersedia. Mengingat hal tersebut sangat dirasakan perlunya supervisi yang berkesinambungan dengan program yang terarah dan sistematis terhadap guru. Program supervisi guru tersebut lazim disebut supervisi yang merupakan suatu rangkaian penting dalam manejemen pendidikan.

Adapun fungsi utama dari supervisi pendidikan seperti yang dikemukakan 
oleh Sahertian, bahwa fungsi dasar dari supervisi adalah untuk memperbaiki situasi belajar mengajar di sekolah agar lebih baik. Supervisi terhadap proses belajar mengajar, merupakan salah satu bentuk aktivitas yang direncanakan untuk membantu para guru dalam melakukan pekerjaan mereka secara efektif (Saryani, 2015)

\section{Rumusan Masalah}

Bagaimana peran supervisi dan administrasi pendidikanuntuk meningkatkan mutu pendidikan nasional

\section{Tujuan Masalah}

Untuk menjelaskan tata pelaksanaan supervisi pendidikan agar mampu meningkatkan mutu pendidikan.

\section{PEMBAHASAN}

Mutu merupakan sesuatu yang dianggap salah satu bagian penting, karena mutu pada dasarnya menunjukkan keunggulan suatu produk jika dibandingkan dengan produk lainnya. Penignkatan mutu merupakan usaha dari setiap lembagalembaga penghasil produk barang tetapi juga produk jasa.

Upaya dalam peningkatan mutu pendidikan merupakan isu yang terus menerus akan menjadi perbincangan dalam pengelolan/ manajemen pendidikan. Peningkatan mutu pendidikan merupakan usaha yang harus diupayakan dengan terus menerus agar harapan untuk pendidikan yang berkualitas dan relevan dapat tercapai.

Pendidikan yang berkualitas merupakan harapan dan tuntutan seluruh stakeholder pendidikan. Semua orang tentunya akan lebih suka menntut ilmu pada lembaga yang memiliki mutu yang baik. Atas dasar ini maka sekolah/ lembaga pendidikan harus dapat memberikan pelayanan dan mutu yang baik agar tidak ditinggalkan dan mampu bersaing dengan lembaga pendidikan lainnya.

Upaya dalam peningkatan mutu pendidikan merupakan isu yang terus menerus akan menjadi perbincangan dalam pengelolan/ manajemen pendidikan. Peningkatan mutu pendidikan merupakan usaha yang harus diupayakan dengan terus menerus agar harapan untuk pendidikan yang berkualitas dan relevan dapat tercapai.

Sergiovani (1982) mengemukakan bahwa supervisi bukan hanya dilakukan oleh pejabat yang sudah ditunjuk tetapi oleh seluruh personel yang ada di $\operatorname{sekolah}($ by the entire school staffs). Tujuan utama dari kegiatan supervisi adalah meningkatkan kualitas pembelajaran, yang harapan akhirnya juga pada prestasi belajar siswa.Tentu saja peningkatan tersebut tidak dapat hanya mengenai satu aspek saja, tetapi 
semua unsur yang terkait dalam proses pembelajaran, antara lain siswa itu sendiri, guru dan personel lain, peralatan, pengelolaan, maupun lingkungan tempat belajar (Widodo, 2017).

Perkembangan supervisi dewasa ini lebih menekankan kepada upaya guru untuk mengembangkan kualitas pembelajarannya melalui pengembangan keprofesionalan berkelanjutan.(Sabandi, 2013)

Guru memiliki peran strategis untuk mewujudkan visi dan tujuan pendidikannasional melalui proses pembelajaran. Perkembangan teknologi informasi tidak dapat menggeser guru dalam pengelolaan dan kepemimpinan proses pembelajaran. Sebagai pengelola pembelajaran, guru melakukan perencanaan, pelaksanaan, pengawasan dan evaluasi pembelajaran. Sebagai pemimpin, guru akan memotivasi, mengarahkan dan menciptakan pengaruh agar siswa berperilaku positif. Teknologi informasi diberdayakan untuk pemecahan kesulitan belajar dan meningkatkan akselerasi dalam pengembangan potensi peserta didik. Standar proses merupakan salah satu dari 8 standar nasional pendidikan (SNP) sebagai kriteria minimal mutu pendidikan. Standar yang lain adalah standar kompetensi lulusan, isi, standar kompetensi lulusan; standar pendidik dan tenaga kependidikan;

standar sarana dan prasarana; standar pengelolaan; standar pembiayaan; dan standar penilaian pendidikan (PP 19 Tahun 2005 dan PP Nomor 32 Tahun 2013). Standar proses mencakup perencanaan proses pembelajaran,pelaksanaan, penilaian, dan pengawasan proses pembelajaran. Dalam perencanaan guru akan menetapkan tujuan, kegiatan dan materi serta media yang relevan dengan kebutuhan peserta didik. Perencanaan ini menjadi acuan dalam proses, penilaian hasil pembelajaran. Guru menjadi aktor strategis dalam pencapaian mutu pendidikan. Sejak perencanaan, implementasi dan penilaian pembelajaran, peran guru menetapkan target mutu, motivator, inspirator dan kontrol lingkungan belajar agar terfokus pada tercapai mutu pendidikan. Sementara itu Kepala dan Pengawas Sekolah akan melakukan supervise kepada guru dalam menyusun Rencana Pelaksanaan Pembelajaran (RPP), pembelajaran dan evaluasi.

Perencanaan menjadi hal yang penting untuk mengetahui bagaimana proses belajar dan tujuan yang akan dicapai. Pernyataan tersebut sejalan dengan Sudaryo dalam Sholeh (2007: 130) yang menegaskan bahwa perencanaan pembelajaran sangat penting 
yang harus disadari sepenuhnya oleh guru sehingga dapat menciptakan proses pembelajaran yang mencerdaskan. Diperkuat oleh pendapat Astowo (2013: 174) yang mengatakan kejelasan tugas menjadi tanggungjawab guru, kejelasan hasil, kejelasan waktu yang diperlukan untuk menyelesaikan pekerjaan dibutuhkan perencanaan yang baik. (Atika :2017:5) Standar proses merupakan salah satu indikator belum tercapaianya standar nasional pendidikan di sekolah. Penelitian dengan sampel 13 sekolah, menunjukkan tingkat kesenjangan pencapaian standar proses sekitar $62,60 \%$ dengan kriteria cukup senjang. Aspek perencanaan diperoleh persentase $75,2 \%$ dengan kriteria tidak senjang, pada aspek pelaksanaan diperoleh persentase $62,58 \%$ dengan kriteria cukup senjang, dalam hal penilaian diperoleh persentase $57,92 \%$ dengan kriteria cukup senjang, dan komponen pengawasan diperoleh persentase. $62,2 \%$ dengan kriteria cukup senjang. (Atika:2017:14)

Guru sebagai tenaga pendidik sangat berperan dalam menentukan proses dan hasil pendidikan yang bermutu, karena pendidik berinteraksi secara langsung dengan peserta didik dalam proses belajar mengajar, membantu, mengarahkan dan membimbing peserta didik guna mencapai tujuan pendidikan yang diharapkan. Selain itu untuk meningkatkan kompetensinya guru sebagai tenaga pendidik yang profesional tidak terlepas dari bimbingan dan pembinaan yang berkesinambungan dari pengawas (Ali Sudin: 2008). Pengawas selaku pembina guru dan kepala sekolah, harus memiliki kesiapan untuk memberikan solusi bagi permasalahan yang mereka hadapi. Oleh karena itu pengawas dituntut meningkatkan kemampuan profesionalnya sebagai penjamin mutu 2009: 74). Sekolah adalah lembaga pendidikan formal penyelenggara kegiatan proses belajarmengajar sebagai upaya untuk tercapainya tujuan pendidikan. Mutu pendidikan sangat dipengaruhi oleh baik buruknya kualitas proses pembelajaran guru, karena guru secara langsung atau tidak memberikan bimbingan dan bantuan kepada siswa dalam upaya mencapai tujuan pendidikan. Kepala sekolah merupakan center leader yang memanage aktivitas program kerja sekolah menjadi terarah, terfokus, dan mengalami peningkatan yang signifikan.

Kegiatan supervisi pada dasarnya adalah proses pembimbingan yang dilakukan kepala sekolah dan guru senior kepada guru dan para personalia sekolah lainnya yang langsung menangani belajar para siswa untuk memperbaiki situais belajar mengajar, agar 
para siswa dapat belajar secara efektif dengan prestasi belajar yang semakin meningkat (Pidarta, 1999). Supervisi merupakan kegiatan pembimbingan yang bersifat manusiawi melalui hubungan yang demokratis, keterbukaan dan persahabatan (Bafadal, 1992). Selain itu kegiatan supervisi direncanakan untuk membantu guru dalam memberikan pengajaran kepada siswa agar aktif belajar sehingga tujuan organisasi sekolah dapat tercapai.(Ismanto, 2016)

\section{PENUTUP}

\section{Kesimpulan}

Pendidikan sangat penting dalam kelangsungan hidup bangsa. Pendidikan berkualitas sangatlah diperlukan dalam usaha untuk kemajuan bangsa dan negara.Perbincangan mengenai pelaksanaan pendidikan tidak lepas dari adanya problematika

Salah satu jalan keluar yang dapat diambil sebagai sebuah keharusan adalah adanya supervisi yang mendorong semangat pengajar dan tenaga kependidikan melakukan yang lebih baik dan tepat guna.

Supervisi pendidikan pada dasarnya merupakan upaya melakukan pembinaan, pengawasan dan pembimbingan terhadap pencapaian standar mutu yang telah ditetapkan demi sebuah proses pendidikan yang ideal. Pembinaan yang komitmen terhadap proses pembelajaran dengan didasari peningkatan mutu yang baik, maka akan pembinaan menjadi manusia yang berkualitas dapat terealisasi dengan optimal.

\section{Saran}

Bagi Pemerintah hendaknya memperhatikan secara menyeluruh dan teliti mengenai mutu pendidikan di lembaga pendidikan.

1. Bagi kepala sekolah, selalu memotivasi dan membina guru agar lebih meningkatkan dan mempertahankan kinerjanya dalam meningkatkan mutu sekolah.

2. Kepada guru kinerjanya harus lebih ditingkatkan untuk mewujudkan tujuan pendidikan dan target kurikulum.

\section{DAFTAR REFERENSI}

Ismanto, B. (2016). Peningkatan Mutu Pembelajaran Melalui Supervisi Akademik Berdasarkan Mutu Standar Proses Pembelajaran ( Studi Kasus Pemetaan Mutu Pendidikan di Provinsi Jawa Tengah ). Retrieved from https://www.google.com/search?client=fire fox-b-

$\mathrm{d} \& \mathrm{q}=$ Peningkatan+Mutu+Pembelajaran + Melalui+Supervisi+Akademik+Berdasarka $\mathrm{n}+$ Mutu+Standar+Proses+Pembelajaran $+\%$ $28+$ Studi+Kasus+Pemetaan+Mutu+Pendid $\mathrm{ikan}+\mathrm{di}+$ Provinsi+Jawa+Tengah+\% 29 .

Sabandi, A. (2013). Supervisi Pendidikan Untuk Pengembangan Profesionalitas Guru Berkelanjutan. Jurnal Ilmiah Ilmu Pendidikan, XIII(2), 1-9.

Saryani, C. (2015). IMPLEMENTASI SUPERVISI PENDIDIKAN DALAM MENINGKATKAN PROSES PEMBELAJARAN DI MIN SUKADAMAI KOTA BANDA ACEH. 16(1), 23-42.

Widodo, J. (2017). SUPERVISI GURU MATA PELAJARAN EKONOMI DI INDONESIA : ANTARA TEORI DAN REALITA. Pendidikan Ekonomi, 2(2), 291-313. 
